\title{
Bovine Mastitis: Prevalence, Isolation of Bacterial Species Involved and its Antimicrobial Susceptibility Test around Debrezeit, Ethiopia
}

\section{Tesfaye Belachew*}

Assela Regional Animal Health Diagnostic Laboratory, Assela, Oromiya, Ethiopia

\begin{abstract}
A total of 300 local zebu lactating cows of small holders farmers around Debrezeit were examined to determine the prevalence of mastitis with associated risk factor, isolate bacterial pathogens involved and its antimicrobial susceptibility profiles. Clinical prevalence was determined through examination of abnormalities of milk and udder and California Mastitis Test (CMT) were used for determining subclinical mastitis. Bacterial culture and Agar disc diffusion was used for isolation and antibiotic susceptibility test. Based on the result out of $18(6 \%)$ positive samples, $2(0.7 \%)$ were clinical and the other $16(5.3 \%)$ were sub-clinical mastitis. Among the potential risk factors considered, there was significant difference $(P<0.05)$ between semi-intensive and extensive farming system. All positive samples were positive for aerobic bacteria. The bacterial species isolated were CNS and Micrococcus species $22.2 \%$, Staphylococcus aureus 16\% Staphylococcus epidermis and Mycoplasma species $11.1 \%$, Enterococcus species, Streptococcus agalactiae and Staphylococcus hycus were 5.65\%. Comparing the overall efficacy of antimicrobials on isolate kanamycin was the most effective antibiotic where $85.7 \%$ of the total isolate were found to be susceptible.
\end{abstract}

Keywords: Antimicrobial susceptibility; Bacterial pathogen; CMT; Bovine mastitis; Subclinical mastitis

Abbreviations: AWARDO: Ada Woreda Agriculture and Rural Development Office; DARC: Debrezeit Agricultural Research Center; CMT: California Mastitis Test; CNS: Coagulase Negative Staphylococci; FAO: Food and Agricultural Organization; masl: Meter above Sea Level; NVI: National Veterinary Institute; NMC: National Mastitis Council; MOARD: Ministry of Agriculture and Rural Development.

\section{Introduction}

Mastitis is the resulted from injurious agents including pathogenic microorganisms, trauma and chemical irritants [1]. According to Quinn et al. [2] over 130 different microorganisms have been isolated from bovine mastitic milk samples, of which almost all are bacteria. The most common pathogen comprises contagious bacteria mainly $S$. aureus and $S$. agalactiae and environmental bacteria mainly coli forms and some species of streptococci that are commonly present in the environment $[1,3]$.

Mastitis infection is spread to teats between milking with organism being transferred up in to udder during milking process itself. Streptococcus uberis is the bacteria causing the majority of the problems, due to its resistance to treatment and chronic infections result in high cell count $[4,5]$.

Mastitis causes milk unsuitable for human consumption or provide a mechanism for the spread of diseases like tuberculosis, Streptococcal intoxication, colibacillosis, Streptococcal sore throat and Brucellosis to human [1]. Public hazards associated with the consumption of antibiotic contaminated milk and products cause allergic responses, changes in intestinal flora and development of antibiotic resistant pathogenic bacteria [6].

Besides, mastitis has been recorded as one of the major disease of economic importance in dairy industry worldwide. It causes greater economic loss: much of the losses are related to production lose from inflammation of the infected quarters [4,5]. Owing to the heavy financial implication involved and the inevitable existence of latent infection, mastitis is obviously an important factor that limits dairy production. Evidence to date shows that affected dairy cows may lose $15 \%$ of their production and the affected quarter a $30 \%$ reduction in productivity. To these gross losses could be added losses associated with its keeping quality and manifesting processes. The disease is also responsible for high percentage of the cows being culled from the dairy herd. Change in milk quality, the possibility of permanent blindness to one or more quarter or even entire udder and death of the cow can resulted from the disease interims of economic loss, it is undoubtedly the most important disease which the dairy industry has to embark upon [1].

In Ethiopia, cows represent the largest proportion of cattle population. According to the food and agriculture organization [7], $42 \%$ of the total cattle heads for the private holding are milking cows. Milk produced from these animals provides important dietary sources for the majority of urban and per urban population. However, milk production often doesn't satisfy the country's requirement due to multitude of factors contributing disease of the mammary glands known as mastitis which is among the leading various factors contributing to reduced milk production [8]. According to Lema et al. [9], of the major diseases of cross bred cows in Addis Ababa milk shed, clinical mastitis was the second most frequent disease next to reproductive diseases in which 171 cows out of 556 were found to be affected with mastitis.

The control of mastitis in dairy herds is accomplished in part with the aid of antibiotic; however, it is not the entire answer to the problem. In addition, indiscriminate uses of drugs which are widely used in the country have potential effect on the development of resistant bacteria. Due to complexity of problem of mastitis in Ethiopia the application

*Corresponding author: Tesfaye Belachew, Assela Regional Animal Health Diagnostic Laboratory, Assela, Oromiya, Ethiopia, Tel: +251933864966; E-mail: teyobeku@gmail.com

Received June 20, 2016; Accepted October 24, 2016; Published October 28 2016

Citation: Belachew T (2016) Bovine Mastitis: Prevalence, Isolation of Bacterial Species Involved and its Antimicrobial Susceptibility Test around Debrezeit, Ethiopia. J Vet Sci Technol 7: 396. doi: 10.4172/2157-7579.1000396

Copyright: (c) 2016 Belachew T. This is an open-access article distributed under the terms of the Creative Commons Attribution License, which permits unrestricted use, distribution, and reproduction in any medium, provided the original author and source are credited. 
of single preventive and control measure is impractical [10]. Hence scrutinizing the degree of the problem of mastitis in dairy cows, assessments of associated risk factors in relation to the type of mastitis, isolation of bacterial causes and testing for antibiotic susceptibility are the core for looking strategic treatment, control and prevention of the disease so as save economic loss from milk, milk product and culling. Based on the above motive the objectives of the study is to determine the prevalence of Bovine mastitis and associated risk factors, isolate and identify the major mastitis causes bacterial and conduct in-vitro antimicrobial susceptibility test of isolates in small holders privately owned Dairy farm around Debre Zeit.

\section{Materials and Methods}

\section{Study methodology}

Study design and population: Across sectional study was conducted to determine the prevalence of both clinical and subclinical mastitis after a total 300 cow's milk samples were collected by simple random sampling from local indigenous lactating cows that are kept by small holder farmers around Debrezeit town under extensive and semi intensive husbandry system.

Data collection: A structured questioner was developed and all information relating to the study objectives were recorded. Data which was recorded includes type of dairy husbandry system, breed, age, parity and location stage, udder and milk abnormalities (injury, blindness, swelling, milk clots, abnormal secretion etc.) were also recorded during sample collection.

Clinical inspection of udder: The udder was examined through visual inspection and palpation to detect possible fibrosis, consistency of mammary quarters, swelling of super mammary lymph nodes, disproportional symmetry of teats, blindness, discoloration of milk, presence of clots, flakes of blood and watery secretions, increased temperature, pain and disturbance of function $[1,2]$.

Detection of mastitis: Mastitis was detected using the CMT and result of clinical inspection of udder. Equal quantity of milk and CMT reagent was added to the cup on a white paddle and gentle swirling was applied to the mixture in horizontal plane. The result of the test was indicated on the basis of gel formation [11]. The interpretation (grades) of CMT was evocated the result grade as for normal 0 and 1, 2, 3, for positive [2].

\section{Microbial investigation of mastitis}

Milk sample collection: Milk was collected before the cow treated with either intra-mammary or systemic antimicrobial agent. For good collection of sample the teats were wiped thoroughly with $70 \%$ ethyl alcohol, paying particular attention to the test orifice and removed the first stripe of milk. The sterile collection bottle will be kept in the crook of the little finger so that the lid does not become contaminated. The milk sample was kept refrigeration from the time of collection to the time of bacteriological examination [2].

Direct Microscopy: The milk sample was centrifuged and stained smears from the deposit. A gram-stain is used routinely. Zehil Nelson staining was done when bacteria such as Mycobacterium bovis are suspected [2].
Culture: The bacteriological culture was formed following the standard microbiological technique and microbiological procedures for the diagnosis of bovine mastitis infection [2,6]. A loop full of milks streaked on 7\% sheep blood agar plates are checked for growth after 24, 48 and up to 72 hours to rule out slow growing microorganisms such as Corynebacterium species sample was considered negative if there is no growth after 72 hours. For primary identification, colony size, shape color hemolytic characteristic, gram reactions were considered. These colonies were sub cultured to get pure colonies to nutrient agar, MacConkey agar, Edwards medium etc. other biochemical Estes.

Characterizations of isolated mastitis causing bacteria was done by different methods, biochemical tests such as catalase, oxidase, coagulase, sugar fermentation test, oxidation fermentation test and indole test. The procedures adapted from Quinn et al. [2] for the identified pathogens were used.

Antimicrobial sensitively testing: Selected bacterial isolates were tested for sensitivity to different antimicrobials. Using in vitro disk diffusion (Kirby-Baur) method as described in [2]. Cultured broth was cross-checked with McFarland to Mueller Hinton agar and disc application. After measuring the zone of inhabitation, it was classified as sensitive, intermediate and resistant according to national committee for clinical laboratory standard (NCCLS) [2].

\section{Statistical analysis}

SPSS version 20 was used to analyze the collected data. The association among and between the considered risk factors were tested by using Chi square $\left(\chi^{2}\right)$ and Odds ratio (OR). The level of significance was also expressed using P-value less than 0.05 .

\section{Results and Discussion}

\section{Prevalence of clinical and sub clinical mastitis}

A total 300 indigenous zebu lactating cows from small holder dairy farm around Debrezeit were examined to determine the prevalence of bovine mastitis. Out of 300 examined cows there was high prevalence of sub clinical mastitis $16(5.3 \%)$ than clinical $2(0.7 \%)$ as shown in Table 1. A total of 1200 quarters were examined and 72(6\%) were CMT positive whereas $33(11.1 \%$ ) were found blind teats (Table 2).

\section{Prevalence of mastitis using multivariate risk factors}

The prevalence of mastitis using multivariate risk factors was shown in Table 3 . Those cows with different lactation stage and farming system revealed significant difference $(\mathrm{p}<0.05)$ in prevalence of mastitis $(\mathrm{p}>0.05)$. The prevalence of both clinical and sub-clinical mastitis by risk factors were insignificance $(\mathrm{P}>0.05)$ with treatment history, lactation stage and parity however, there was significance difference between semi intensive and extensive farming system $(\mathrm{P}<0.05)$. The proportions of sub-clinical mastitis were higher than clinical one within all current considered risk factors Table 4.

A total of 18 cows that were positive both clinically and sub clinically, all samples were collected and cultured. From 18 cultured samples, $18(100 \%)$ samples were positive for aerobic bacteria. The isolated bacterial species and were presented below in Table 5 . Coagulase Negative Staphylococcus (CNS) and Micrococcus species were

\begin{tabular}{|c|c|c|}
\hline \multirow{2}{*}{ Number of cows examined } & Clinical mastitis & Sub-clinical mastitis \\
\cline { 2 - 3 } & Positive No. (\%) & Positive No. (\%) \\
\hline 300 & $2(0.7 \%)$ & $16(5.3 \%)$ \\
\hline
\end{tabular}

Table 1: Prevalence of clinical and sub clinical bovine mastitis at Cow level using CMT. 
Citation: Belachew T (2016) Bovine Mastitis: Prevalence, Isolation of Bacterial Species Involved and its Antimicrobial Susceptibility Test around Debrezeit, Ethiopia. J Vet Sci Technol 7: 396. doi: 10.4172/2157-7579.1000396

Page 3 of 6

\begin{tabular}{|c|c|c|c|}
\hline Quarter & CMT Positive No (\%) & CMT Negative No (\%) \\
\hline Left Back & $28(2.33)$ & $1172(97.7)$ \\
\hline Left Front & $24(2)$ & $1176(98)$ \\
\hline Right back & $12(1)$ & $1188(98.7)$ \\
\hline Right Front & $8(0.67)$ & $1192(99.3)$ & 11.2) \\
\hline Over all & $72(6)$ & 1128(9) & 2(0.8) \\
\hline
\end{tabular}

Table 2: Quarter level of prevalence of mastitis and blind teats.

\begin{tabular}{|c|c|c|c|c|}
\hline Risk factor & No of cow Examined & Positive No (\%) & $x^{2}$ & p-value \\
\hline $\begin{array}{l}\text { Location stage } \\
\text { Early } \\
\text { Mid } \\
\text { Late }\end{array}$ & $\begin{array}{c}108 \\
128 \\
64\end{array}$ & $\begin{array}{l}7(6.4) \\
3(16.7) \\
8(44.4)\end{array}$ & 7.873 & 0.020 \\
\hline $\begin{array}{c}\text { Age }(\mathrm{yr}) \\
3.5-6 \\
6-9 \\
9-13\end{array}$ & $\begin{array}{c}134 \\
133 \\
33\end{array}$ & $\begin{array}{l}8(44.5) \\
6(33.3) \\
4(22.2)\end{array}$ & 1.85 & 0.229 \\
\hline $\begin{array}{l}\text { Parity } 1-3 \\
3-6 \\
6-9\end{array}$ & $\begin{array}{l}138 \\
84 \\
78\end{array}$ & $\begin{array}{l}6(33.3) \\
5(27.8) \\
7(38.9)\end{array}$ & 1.892 & 0.388 \\
\hline $\begin{array}{l}\text { Farm system } \\
\text { Extensive } \\
\text { Semi intensive }\end{array}$ & $\begin{array}{c}293 \\
7\end{array}$ & $\begin{array}{c}14(77.7) \\
4(22.2)\end{array}$ & 39.953 & 0.000 \\
\hline $\begin{array}{c}\text { History treatment } \\
\text { Treated } \\
\text { Untreated }\end{array}$ & $\begin{array}{l}187 \\
113\end{array}$ & $\begin{array}{c}10(55.6) \\
8(44.4)\end{array}$ & 0.338 & 0.561 \\
\hline
\end{tabular}

Table 3: The prevalence of mastitis within the considered risk factors.

\begin{tabular}{|c|c|c|c|c|c|}
\hline \multirow[b]{2}{*}{ Risk factors } & & \multicolumn{2}{|c|}{ Type of mastitis positive } & \multirow[t]{2}{*}{$x^{2}$} & \multirow[t]{2}{*}{ p-value } \\
\hline & & $\begin{array}{l}\text { Clinical } \\
\text { No (\%) }\end{array}$ & $\begin{array}{l}\text { Sub clinical } \\
\text { No (\%) }\end{array}$ & & \\
\hline $\begin{array}{l}\text { Treatment history } \\
\text { Treated }\end{array}$ & 114 & $1(50)$ & $9(56.2)$ & 0.367 & \multirow{2}{*}{0.832} \\
\hline Untreated & 186 & $1(50)$ & $7(43.8)$ & & \\
\hline $\begin{array}{l}\text { Location stage } \\
\text { Early }\end{array}$ & 108 & $1(50)$ & $6(37.5)$ & & \\
\hline Mid & 128 & $0(0)$ & $3(18.8)$ & 8.129 & 0.089 \\
\hline Late & 64 & $1(50)$ & $7(43.8)$ & & \\
\hline $\begin{array}{l}\text { Age (year) } \\
3.5-6\end{array}$ & 134 & $1(50)$ & $(57.8)$ & & \\
\hline $6-9$ & 133 & $1(50)$ & $62(54.9)$ & 4.145 & 0.387 \\
\hline $9-13$ & 33 & $0(0)$ & $35(53.0)$ & & \\
\hline Parity $1-3$ & 138 & $1(50)$ & $6(37.5)$ & & \\
\hline $3-6$ & 84 & $1(50)$ & $4(25)$ & 1.892 & 0.388 \\
\hline $6-9$ & 78 & $0(0)$ & $6(37.5)$ & & \\
\hline Farm system Extensive & 293 & $2(100)$ & $12(75)$ & 45.622 & 0.000 \\
\hline Semi intensive & 7 & $0(0)$ & $4(25)$ & & \\
\hline
\end{tabular}

Table 4: Prevalence of clinical and sub clinical mastitis in different risk factor.

isolated with high prevalence (22.2\%), Staphylococcus aureus $16.7 \%$, Staphylococcus intermedius and Mycoplasma species were $11.1 \%$, and Streptococcus agalactiae, Enterococcus species and Staphylococcus hycus were $5.6 \%$.

From the tested bacterial isolate using selected antimicrobial agent all are susceptible for kanamycin and except one isolate of CNS. CNS shows intermediate (50\%) for both Chloramphinacol and Kanamycin as shown in Table 6.

\section{Discussion}

In this study, the overall bovine mastitis prevalence is $6 \%$. The prevalence is very less compared to the others study finding done on mastitis elsewhere in Ethiopia such as $52.27 \%$ by Abunna et al. [12], $34.9 \%$ by Biffa et al. [13], 74.7\% by Zeryehun et al. [14] and Ashenafi [15] who reported $75 \%$ prevalence. This might be due to management system the farmers have practiced in the study area. Farmers have maximum of cow 2-3 and they release their cows to open grazing land this system decreases the chance of transmission of contagious mastitis between cows [1]. Up on taking history on the cows' production of milk, they only give less than 1.5 liter/day. Local Zebu breed are low in milk production and resistant to mastitis [16]. Higher yielding cows have been found more susceptible to mastitis owing to position of teats, udder, and anatomy of teat cannel making them prone to injury, and due to fewer efficacies of pathogenic cells in higher yielding cows associated to dilution $[1,17]$. 
Citation: Belachew T (2016) Bovine Mastitis: Prevalence, Isolation of Bacterial Species Involved and its Antimicrobial Susceptibility Test around Debrezeit, Ethiopia. J Vet Sci Technol 7: 396. doi: 10.4172/2157-7579.1000396

Page 4 of 6

The clinical mastitis prevalence in this study was $0.7 \%$ which was comparable with that of Gizat [18], who reported $0 \%$ in local Zebu lactating cows in and around Bahir Dar. However, the present finding was lower than that of Tesfaye [19], who reported 7.3\% in Adama, and Adugna [20], who reported 5.7\% in Dire Dawa and Haramaya University Dairy farm. Most of the time when comparing clinical and sub-clinical mastitis, clinical mastitis is lower than that of subclinical mastitis and this is because of treatment of clinical mastitis is commonly practiced [19].

In Ethiopia, the sub-clinical mastitis received little attention and efforts have been concentrated on the treatment of clinical cases while the high economic loss could come from sub-clinical mastitis [21]. The present finding of prevalence of sub-clinical mastitis was $5.3 \%$ which is comparable with that of Tesfaye [19] who reported 7.3\% in Adama and less than that of Adugna [20] who reported $18.9 \%$ in Dire Dawa and Haramaya University Dairy farm and Gizat [18] who reported $17 \%$ in and around Bahir Dar on the local Zebu lactating cows. In the present study, as well in other conducted studies, over whelming cases of mastitis were sub-clinical compared to clinical mastitis [22,23].

Dairy farms in the study area usually complain about the decrease in milk yield irrespective of adequate feed provision and deworming practice. The high prevalence of sub-clinical mastitis may be due to attributed to improper milking hygiene, poor house hygiene, lack of post milking teat dipping and practicing of milk by contact labors use of lubricant, absence of order in milking cows of different ages. Moreover, its occurrence was high in dairy farms without noticeable in farm treatment as Radostitis et al. [1] and Quinn et al. [2] provide the same reasoning.

The prevalence of mastitis which was not significantly influenced by considered potential risk factor $(\mathrm{P}>0.05)$ are age, parities, and treatment history. But lactation stage and farming system are significantly the potential risk factors. This could be due to as lactation stage increases chance of cows exposed to the mastitis increases because daily contact of cows while milking and in farming system with no care milking management.

From total examined 1200 quarters $72(6 \%)$ quarter were CMT positive and $33(11.1 \%)$ blind teats. Blindness of the teat could be due to failure to detect the disease in early stage attributable to lack of strip cup examination and skill milker's to establish a prompt treatment. Generally, it indicates a poor treatment regime and husbandry [6].

Analysis of the bacteriological examination of the milk samples was made to isolate and identify the main etiological agents involved in the disease process. The organisms were identified on the bases of their culture, staining characteristics and biochemical reactions. The result of bacteriological analysis in the present study showed that Coagulase Negative Staphylococcus and Micrococcus species were predominant pathogens which were $22.2 \%$ of all the isolated bacterial species. The high isolation rate of CNS in the study could be associated with it characteristics of chronicity. The CNS isolated was all found from sub-clinical mastitis. However, CNS was isolated from bovine and other dairy animals' mastitic milk samples which indicated that they could be pathogenic even causes more mastitis than S. aureus [24]. According to Pyorolla, over $30 \%$ sub-clinical and nearly $20 \%$ of acute cases of mastitis were usually due to CNS which is in agreement with the present result (22.2\%). The isolated Micrococcus species $(22.2 \%)$ was comparable with the finding of Amen et al. who reported $26.67 \%$ in different parts of Ethiopia and it was higher than the findings of Tarekegn [6], Gizat [18] and Mekonnen et al. [25] who reported 8.15, 5.2 and $10.2 \%$ respectively.

The isolation rate of $S$. aureus $16.7 \%$ in the present study is the second next to CNS and Micrococcus species and closely comparable with the findings of Gizat [18]. Bishi [24] and Hussein [21] reported $17.8 \%$ and $9 \%$ in Addis Ababa respectively. However, the present finding is lower than that of Workineh et al. [22] and Kerro and Tereke

\begin{tabular}{|c|c|c|}
\hline No. & Isolates Frequency & No (\%) \\
\hline 1. & Staphylococcus aureus 3 & $16.7 \%$ \\
\hline 2. & Micrococcus Species 4 & $22.2 \%$ \\
\hline 2. & Staphylococcus hycus 1 & $5.6 \%$ \\
\hline 4 & Staphylococcus intermedius 2 & $11.1 \%$ \\
\hline 5. & Streptococcus agalactiae 1 & $5.6 \%$ \\
\hline 6. & Mycoplasma species 2 & $11.1 \%$ \\
\hline 7. & Coagulase Negative Staphylococcus 4 \\
\hline 8. & Enterococcus species 1 \\
\hline Total & $\mathbf{1 8}$ \\
\hline
\end{tabular}

Table 5: Isolated bacteria species from CMT Positive milk sample.

\begin{tabular}{|c|c|c|c|c|c|c|c|c|c|c|c|c|c|c|c|c|}
\hline \multicolumn{17}{|c|}{ Response to application of antimicrobial disks (\%) } \\
\hline $\begin{array}{l}\text { Bacteria } \\
\text { isolates }\end{array}$ & $\mathbf{N}$ & \multicolumn{3}{|c|}{$\mathrm{C}_{30}$} & \multicolumn{3}{|c|}{$\mathbf{A P}_{10}$} & \multicolumn{3}{|c|}{$\mathrm{TE}_{30}$} & \multicolumn{3}{|c|}{$A X_{10}$} & \multicolumn{3}{|c|}{$\mathrm{K}_{30}$} \\
\hline & & $\mathbf{S}$ & $\mathbf{I}$ & $\mathbf{R}$ & $\mathbf{S}$ & I & $\mathbf{R}$ & $\mathbf{S}$ & $\mathbf{I}$ & $\mathbf{R}$ & $\mathbf{S}$ & $\mathbf{I}$ & $\mathbf{R}$ & $\mathbf{S}$ & $\mathbf{I}$ & $\mathbf{R}$ \\
\hline S. aureus & 2 & $1(50 \%)$ & $1(50 \%)$ & & & $2(100 \%)$ & - & - & - & $2(100 \%)$ & $1(50 \%)$ & $1(50 \%)$ & - & $2(100 \%)$ & - & - \\
\hline $\begin{array}{c}\text { S. } \\
\text { intermedius }\end{array}$ & 1 & $1(100 \%)$ & - & - & $1(100 \%)$ & - & - & - & $1(100 \%)$ & - & $1(100 \%)$ & - & - & $1(100 \%)$ & - & - \\
\hline $\begin{array}{c}\text { Micrococcus } \\
\text { Sp. }\end{array}$ & 2 & $1(50 \%)$ & $1(50 \%)$ & - & $1(50 \%)$ & $1(50 \%$ & - & $2(100 \%)$ & - & - & $2(100 \%)$ & - & - & $2(100 \%)$ & - & - \\
\hline CNS & 2 & - & $1(50 \%)$ & $1(50 \%)$ & - & - & - & $2(100 \%)$ & - & - & $2(100 \%)$ & - & - & - & $2(100 \%)$ & - \\
\hline S. hycus & 1 & - & $1(100 \%)$ & - & $1(100 \%)$ & $1(100 \%$ & - & & - & - & - & - & $1(100 \%)$ & $1(100 \%)$ & - & - \\
\hline Enterococci & 1 & $1(100 \%)$ & - & - & - & - & - & & - & - & - & $1(100 \%)$ & - & $1(100 \%)$ & - & - \\
\hline S. agalactae & 1 & - & $1(100 \%)$ & - & $1(100 \%)$ & - & - & & $1(100 \%)$ & - & $1(100 \%)$ & - & - & - & $1(100 \%)$ & - \\
\hline
\end{tabular}

Keys: N: Number of observations; AX: Amoxicillin; C: Chloramphnicol; I: Intermediate K: Kanamycin, R: Resistance, S: Susceptible, TE: Tetracycline

Table 6: Antibiotic sensitivity testing. 
Citation: Belachew T (2016) Bovine Mastitis: Prevalence, Isolation of Bacterial Species Involved and its Antimicrobial Susceptibility Test around Debrezeit, Ethiopia. J Vet Sci Technol 7: 396. doi: 10.4172/2157-7579.1000396

[10] where S. aureus account 39.2 and $40.5 \%$ isolates respectively in Addis Ababa and Sothern Ethiopia. The relatively high prevalence of S. aureus in this study could be associated with total absence of dry cow therapy and post milking teat dipping, the invariable hold milking practice and low culling rate of chronically infected cows. Culling was usually due to feed shortage, ageing and reproductive problem. Staphylococcus intermidus and Staphylococcus hycus were found in the rate of 11.1 and $5.6 \%$ respectively.

Streptococcus agalactiae was found $5.6 \%$ and this bacterial species was lower isolate in the study area and this could be due to management system in the study area. Environmental Streptococci may be due to poor housing facilities which predispose to the accumulation of feces on cows which could increase the rate of exposure of the teats and udder to the pathogens. Mycoplasma species was found with rate of $11.1 \%$ in the study farms. Mycoplasmas are group of very small organisms that can be cultured from multiple body sites of both sick and healthy cattle. Some common Mycoplasma include M. bovis most commonly cultured from the udder [26]. The organisms were isolated from clinical infected cows which agree with the finding of Thomas [26]. In milk samples obtained from individual cows, a negative Mycoplasma culture usually means that the organism is not present. However, intermittent shedding of organism has been reported, so false negative cultures may rarely occur [27].

When comparing the overall efficacy of antimicrobials on isolates, kanamycin was the most effective antibiotic where $85.7 \%$ of the total isolate were found to be susceptible. The drug was not used in the study area for the treatment of animals. S. aureus was $100 \%$ resistant to Tetracycline. The development of antibiotic resistance nearly always has followed the continuous and under dosage use of the antimicrobial agents [2].

The dominant pathogens in the study area were CNS and Micrococcus species. CNS isolate were $100 \%$ susceptible to Tetracycline, Amoxicillin and Kanamycin however intermediate to Chloramphenicol and Ampicillin (50\%) which is in agreement with the report by Bishi [24].

In this study S. aureus was the most susceptible to Kanamycin and Ampicillin and intermediate to Chloramphenicol, and Amoxicillin 100 and $50 \%$ respectively. A report of Bishi [24] indicated that Tetracycline was not effective in S. aureus.

Micrococcus species were $100 \%$ susceptible to Tetracycline, Amoxicillin and Kanamycin. This might be due to non-drug treatment with Amoxicillin and Kanamycin in the study areas [28]. Staphylococcus hycus, Staphylococcus intermidius and Enterococci species were also 100\% susceptible to Ampicillin, Tetracycline and Kanamycin.

\section{Acknowledgements}

First and foremost, I like to thank the heavenly father God for giving my strength and patience during my all life and study program. I would like to express my deep sincerely appreciation and thanks to Dr. Henok Ayalew, for his intellectual guidance, close supervision and devotion of time in criticizing this paper.

\section{Conflict of Interest}

I declare that this paper presents the work carried out by myself and does not incorporate with the acknowledgement of any material and finance.

\section{References}

1. Radostitis OM, Gay CC, Blood DC, Hinchllif KW (2007) Mastitis. In: Veterinary Medicine. 9th edn. Haracourt Ltd, London, pp: 603-700.

2. Quinn PJ, Carter ME, Markey BK, Carter GR (2002) Clinical Veterinary Microbiology. Harcourt Publishers, Virginia, USA, pp: 331-344.
3. Bhatt VD, Patel MS, Joshi CG, Kunjadia A (2011) Identification and antibiogram of microbes associated with bovine mastitis. Anim Biotechnol 22: 163-169.

4. Erskine RJ (2001) Mastitis control in dairy farms. In: Herd Health, Food Anima Production Medicine. 3rd edn, Radostits OM (eds.). WB Saunders Company, Philadelphia, Pennsylvania, USA, pp: 397-432.

5. Behiry AE, Schlenker G, Szabo I, Roesler U (2012) In vitro susceptibility of Staphylococcus aureus strains isolated from cows with subclinical mastitis to different antimicrobial agents. J Vet Sci 13: 153-161.

6. Kassa T, Wirtu G, Tegegne A (1999) Survey of mastitis in dairy herds in the Ethiopian central highlands. SINET: Ethiopian J Sci 22: 291-301.

7. Akam DN, Dodd FH, Quick AJ (1989). Milking, milk production hygiene and udder health. Vol 78. Food \& Agricultural Organization.

8. Fekadu K (1995) Survey on the prevalence of bovine mastitis and the predominant causative agents in Chaffa valley. In: Proceedings of the 9th Conference of Ethiopian Veterinary Association: Addis Ababa, Ethiopia, pp: 101-111.

9. Lema M, Kassa T, Tegegne A (2001) Clinically manifested major health problems of crossbred dairy herds in urban and periurban production systems in the central highlands of Ethiopia. Trop Anim Health Prod 33: 85-93.

10. Kerro O (1997) A study on bovine mastitis in some selected areas of southern Ethiopia. DVM Thesis, Faculty of Veterinary Medicine, Addis Ababa University, Debre Zeit, Ethiopia.

11. Smith M, Sherman D (1994) Goat medicine. 1st edn. Williams and Wilkins Awaverly Company, USA, pp: 465-487.

12. Abunna F, Fufa G, Megersa B, Regassa A (2013) Bovine Mastitis: Prevalence Risk Factors and Bacterial Isolation in Small-Holder Dairy Farms in Addis Ababa City, Ethiopia. Glob Vet 10: 647-652.

13. Biffa D, Debela E, Beyene F (2005) Prevalence and risk factors of mastitis in lactating dairy cows in Southern Ethiopia. International J Appl Res Vet Med 3: 189-198.

14. Zeryehun T, Aya T, Bayecha R (2013) Study on prevalence, bacterial pathogens and associated risk factors of bovine mastitis in small holder dairy farms in and around Addis Ababa, Ethiopia. J Anim Plant Sci 23: 50-55.

15. Ashenafi G (2008) Prevalence of bovine mastitis, identification of the causative agent and drug sensitivity test in and around kombolcha. DVM. Thesis, FVM Haramaya University, Ethiopia 17: 41-46.

16. Almaw G, Molla B (2000) Prevalence and etiology of mastitis in camels (Camelus dromedarius) in eastern Ethiopia. Journal of Camel Practice and Research 7: 97-100.

17. Schalm W, Carrlole FJ (1971) Bovine mastitis. Led and Teliger, Philadelphia, USA, pp: $1-21$

18. Gizat A (2004) A cross sectional study of Bovine mastitis in and around Bahi Dar and Antibiotics resistance patterns for major pathogens. MSc Thesis, Faculty of Veterinary Medicine, Addis Ababa University, Debrezeit, Ethiopia.

19. Tesfaye A (2007) Small scale dairy farming practice and cross-sectional study of mastitis in Nazareth, East Shoa, Ethiopia. MSc Thesis, Faculty of Veterinary Medicine, Addis Ababa University, Ethiopia.

20. Adugna B (2008) Cross sectional study of mastitis in Dire Dawa and Haramaya University dairy farms, prevalence isolation and identification of pathogens and Antimicrobial sensitivity testing, Eastern Ethiopia. DVM Thesis, FVM Haramaya University, Ethiopia.

21. Hussein N (1999) Cross-sectional and longitudinal study of bovine mastitis in urban and peri-urban dairy systems in the Addis Ababa region, Ethiopia. Doctoral Dissertation, MSc Thesis, Free University of Berlin, Germany and Addis Ababa University, Ethiopia, Joint programme.

22. Workineh S, Bayleyegn M, Mekonnen H, Potgieter LND (2002) Prevalence and aetiology of mastitis in cows from two major Ethiopian dairies. Trop Anim Health Prod 34: 19-25.

23. Dego OK, Tareke F (2003) Bovine mastitis in selected areas of southern Ethiopia. Trop Anim Health Prod 35: 197-205.

24. Bishi AS (1998) Cross-sectional and longitudinal prospective study of bovine clinical and subclinical mastitis in periurban and urban dairy production systems in the Addis Ababa region, Ethiopia. 
Citation: Belachew T (2016) Bovine Mastitis: Prevalence, Isolation of Bacterial Species Involved and its Antimicrobial Susceptibility Test around Debrezeit, Ethiopia. J Vet Sci Technol 7: 396. doi: 10.4172/2157-7579.1000396

Page 6 of 6

25. Mekonnen H, Workineh S, Bayleyegn M, Moges A, Tadele K (2005) Antimicrobial susceptibility profiles of mastitis isolates from cows in three major Ethiopian dairies. Revue Med Vet 156: 391-394.

26. Thomas CB (1998) Bovine Mycoplasmas: A practitioner's orientation to host and agent interaction. In: Proceeding of WI Vet Med Assoc. 84th Ann Conf WI. Vet. Med. Assoc., Madison WI, USA, pp: 55.
27. Jasper DE (1980) Bovine mycoplasmal mastitis. Adv Vet Sci Comp Med 25 121-157.

28. Bramely AJ, Cullor JS, Erskine RJ, Fox LK, Harmon RJ, et al. (1996) Current concepts of bovine mastitis. National Mastitis Council Inc., Arlington, VA, USA 